\title{
Penerapan Creative Problem Solving Model untuk Meningkatkan Kemampuan Pemecahan Masalah Fisika Siswa Kelas XI MIA 4 MAN 2 Kota Bengkulu
}

\author{
Intan Sagita, Rosane Medriati, Andik Purwanto \\ Program Studi Pendidikan Fisika JPMIPA FKIP Universitas Bengkulu \\ J1. Raya Kandang Limun No 1 Bengkulu 38123 \\ E-mail: intansagita9797@gmail.com
}

\begin{abstract}
ABSTRAK
Penelitian ini bertujuan untuk meningkatkan aktivitas belajar siswa dan kemampuan pemecahan masalah fisika siswa. Penelitian ini merupakan penelitian tindakan kelas. Subjek dalam penelitian adalah siswa kelas XI MIA 4 MAN 2 Kota Bengkulu sebanyak 35 orang. Penelitian ini dilakukan dalam empat tahap yaitu perencanaan, pelaksanaan tindakan, obsevasi, dan refleksi. Instrumen pengumpulan data dalam penelitian ini yaitu lembar observasi aktivitas guru dan siswa dan tes kemampuan pemecahan masalah. Analisis data dalam penelitian ini adalah analisis deskriptif untuk melihat peningkatan aktivitas belajar siswa dan kemampuan pemecahan masalah fisika siswa. Hasil analisis data menunjukkan bahwa aktivitas belajar siswa pada siklus I dengan rata-rata skor sebesa 24 (kategori baik), siklus II sebesar 26,5 (kategori baik), dan siklus III sebesar 28 (kategori baik). Kemampuan pemecahan masalah pada siklus I sebesar 71,69 dengan kategori sedang dan ketuntasan belajar secara klasikal 60\% (belum tuntas secara klasikal), pada siklus II kemampuan pemecahan masalah sebesar 78,71 dengan kategori sedang dan ketuntasan belajar klasikal 77,14 (belum tuntas secara klasikal), dan pada siklus III kemampuan pemecahan masalah sebesar 86,94 dengan kategori tinggi dan ketuntasan belajar secara klasikal 88,57 (tuntas secara klasikal). Bedasarkan hasil penelitian dapat disimpulkan bahwa penerapan model creative problem solving dapat meningkatkan aktivitas belajar dan kemampuan pemecahan masalah siswa.
\end{abstract}

Kata kunci: Model Creative Problem Solving, Aktivitas Belajar, Kemampuan Pemecahan Masalah.

\begin{abstract}
This study was aimed to improve students learning activities and students abilities to solve physics problems. This research was a classroom action reseach. The subjects of the study were students of class XI MIA 4 MAN 2 Bengkulu which amount was 35 people. The research was conducted in four stages: planning, implementation of action, observation, and reflection. The data was collected by using observation sheet for teacher and student activity and also by problem solving test. The data of this research was analyzed descriptively to see the improvement of student learning activities and problem-solving abilities The results showed that student learning activity in cycle I had average score 24 (good category), cycle II was 26,5 (good category), and cycle III was 28 (good category). Problem solving ability in cycle I was 71,69 with medium category and classical learning completeness was 60 (not yet completed classically), in cycle II problem solving ability equal to 78,71 (medium category) and classical learning completeness was 77,14 (not yet completed classically), and in cycle III problem solving ability equal to 86,94 (high category) and classical learning achievement was 88,57 (completed classically). Based on the result of the research, it can be concluded that the application of creative problem solving model can improve learning activities and problem solving abilities of students.
\end{abstract}

Keywords: Creative Problem Solving Model, Learning Activity, Problem Solving Ability.

\section{PENDAHULUAN}

Fisika adalah salah satu cabang sains yang besar peranannya dalam kemajuan IPTEK. Dalam prosesnya, pembelajaran fisika menekankan siswa mengkonstruksi dan menemukan pengetahuannya sendiri. Fisika juga merupakan mata pelajaran yang dapat menumbuhkan kemampuan pemecahan masalah siswa. Oleh karena itu, dalam pembelajaran fisika siswa dituntut untuk membangun dan menemukan sendiri pengetahuannya sehingga dapat memecahkan masalah fisika. 
Pemecahan masalah adalah upaya mancari jalan keluar dari suatu masalah yang dihadapi oleh siswa. Suharsono dalam Wena (2012) mengatakan bahwa kemampuan pemecahan masalah sangat penting bagi siswa dan masa depannya. Para ahli pembelajaran sependapat bahwa dalam batas-batas tertentu kemampuan pemecahan masalah siswa dapat dibentuk melalui bidang studi dan disiplin ilmu yang diajarkan. Proses pembelajaran berdasarkan kemampuan pemecahan masalah harus dirancang sedemikian rupa sehingga mampu merangsang siswa untuk berpikir dan mendorong siswa menggunakan pikirannya secara sadar untuk memecahkan masalah[1].

Berdasarkan hasil observasi di kelas XI MIA 4 MAN 2 Kota Bengkulu ditemukan beberapa fakta bahwa: (1) guru yang lebih banyak terlibat aktif pada proses pembelajaran fisika di kelas, kegiatan pembelajaran diawali dengan penyampaian teori dari guru, siswa mencatat materi yang diberikan guru, (2) keaktifan siswa dalam proses pembelajaran masih rendah. Pada saat pembelajaran berlangsung, hanya sekitar 30\% siswa yang terlibat aktif dalam pembelajaran, (3) siswa belum terlatih untuk menjawab soal secara mandiri dan belum terampil dalam mengenali, mengidentifikasi, menggambarkan permasalah dalam sebuah soal, serta masih bingung memilih persamaan yang akan digunakan untuk menyelesaikan soal, (4) hasil belajar fisika siswa aspek pengetahuan masih rendah, hal ini dapat dilihat dari hasil ulangan harian fisika siswa kelas XI MIA 4. Dari 35 orang siswa hanya $34 \%$ (12 orang) siswa yang tuntas pada saat ulangan sedangkan $66 \%$ (23 orang) siswa lainnya mendapatkan skor dibawah kriteria ketuntasan minimun (KKM) yang ditetapkan sekolah yaitu 75 .

Untuk mengatasi permasalahan yang dihadapi pada pembelajaran fisika, perlu adanya perubahan pada proses pembelajaran. Guru perlu memilih model pembelajaran yang tepat sehingga dapat meningkatkan aktivitas belajar dan kemampuan pemecahan masalah fisika siswa. Salah satu model pembelajaran yang diharapkan dapat meningkatkan aktivitas belajar dan kemampuan pemecahan masalah fisika siswa adalah model Creative Problem Solving. Pepkin dalam Supardi \& Putri (2010) mengatakan model Creative Problem Solving adalah suatu model pembelajaran yang melakukan pemusatan pada pengajaran dan keterampilan pemecahan masalah, yang diikuti dengan penguatan keterampilan[2].

Parmes dalam Suryosubroto (2009) mengemukakan adanya lima langkah yang melibatkan imajinasi dan pembenaran dalam menangani situasi dan pembahasan suatu masalah. Langkah langkah Creative Problem Solving tersebut bila diterapkan dalam pembelajaran, yaitu (1) penemuan fakta, mengajukan pertanyaan sesuai dengan pokok/sub pokok bahasan, (2) penemuan masalah, berdasarkan fakta-fakta yang telah dihimpun, ditentukan masalah/pertanyaan kreatif untuk dipecahkan, (3) penemuan gagasan, menjaring sebanyak mungkin alternatif jawaban untuk memecahkan masalah, (4) penemuan jawaban, menentukan tolak ukur atas kriteria pengujian jawaban, sehingga ditemukan jawaban yang diharapkan, dan (5) penentuan penerimaan, diketemukan kabaikan dan kelemahan gagasan, kemudian menyimpulkan dari masing-masing masalah yang dibahas[3].

Model Creative Problem Solving berpusat pada pemecahan masalah secara kreatif dan diharapkan membuat siswa mampu mengambangkan kemampuannya dalam menyelesaikan masalah dalam kehidupan sehari-hari yang berkaitan dengan ilmu fisika. Hal ini telah dibuktikan dari hasil penelitian yang dilakukan Hariawan, Kamaluddin, \& Wahyono (2014) yang mengatakan bahwa model Creative Problem Solving berpengaruh secara signifikan terhadap kemampuan siswa dalam memecahkan masalah fisika pada materi elastisitas dan gerak harmonik sedernaha[4]. Kelebihan dari model Creative Problem Solving antara lain: 1) melatih siswa untuk mendesain suatu penemuan, 2) menuntun siswa berpikir dan bertindak kreatif, 3) siswa dapat memecahkan masalah yang dihadapi secara realistis, 4) mengidentifikasi dan melakukan penyelidikan, dan 5) membuat siswa mampu menafsirkan dan mengevaluasi hasil pengamatan[5].

Berdasarkan uraian yang telah dijelaskan di atas, rumusan masalah yang akan dikaji dalam penelitian ini adalah sebagai berikut. (1) Apakah penerapan model Creative Problem Solving dapat meningkatkan aktivitas belajar fisika siswa di kelas XI MIA 4 MAN 2 Kota Bengkulu? (2) Apakah penerapan model Creative Problem Solving dapat meningkatkan kemampuan pemecahan masalah fisika siswa di kelas XI MIA 4 MAN 2 Kota Bengkulu? 
Adapun tujuan dari penelitian ini adalah: (1) Mengetahui peningkatan aktivitas belajar fisika siswa melalui penerapan model Creative Problem Solving di kelas XI MIA 4 MAN 2 Kota Bengkulu. (2) Mengetahui peningkatan kemampuan pemecahan masalah fisika siswa melalui penerapan model Creative Problem Solving di kelas XI MIA 4 MAN 2 Kota Bengkulu.

\section{METODE PENELITIAN}

Penelitian ini merupakan penelitian tindakan kelas (PTK) yang terdiri dari tiga siklus yang setiap siklusnya terdiri dari empat tahapan, yaitu perencanaan, pelaksanaan tindakan, pengamatan dan refleksi. Subyek dalam penelitian ini adalah siswa kelas XI MIA 4 MAN 2 Kota Bengkulu Tahun Ajaran 2017-2018 yang bejumlah 35 orang (11 siswa laki-laki dan 24 siswa perempuan). Teknik pengumpulan data dilakukan dengan instrumen lembar observasi guru dan siswa dan soal tes kemampuan pemecahan masalah.

Analisis data yang digunakan dalam penelitian ini adalah analisis deskiptif yang digunakan untuk melihat peningkatan aktivitas belajar siswa dan peningkatan kemampuan pemecahan masalah setiap siklus dengan indikato memahami masalah, merrencanakan strategi, menerapkan strategi, dan mengevalusi solusi. Kategori kemampuan pemecahan masalah siswa dapat dikelompokkan berdasarkan skor seperti pada Tabel 1.

Tabel 1. Kategori kemampuan pemecahan masalah[6]

\begin{tabular}{cl}
\hline Skor & \multicolumn{1}{c}{ Tingkat Kemampuan } \\
\hline $90 \leq-\leq 100$ & Kemampuan pemecahan masalah sangat tinggi \\
\hline $80 \leq-\leq 89$ & Kemampuan pemecahan masalah tinggi \\
\hline $65 \leq-\leq 79$ & Kemampuan pemecahan masalah sedang \\
\hline $55 \leq-\leq 64$ & Kemampuan pemecahan masalah rendah \\
\hline $0 \leq-\leq 54$ & Kemampuan pemecahan masalah sangat rendah \\
\hline
\end{tabular}

\section{HASIL DAN PEMBAHASAN}

\subsection{Aktivitas Belajar Siswa}

Aktivitas belajar siswa merupakan seluruh kegiatan siswa selama proses pembelajaran berlangsung. Data observasi aktivitas belajar siswa setelah menerapkan model creative problem solving dalam tiga siklus dapat dilihat pada Tabel 2.

Tabel 2. Hasil observasi aktivitas belajar siswa tiga siklus

\begin{tabular}{ccccc}
\hline Siklus & $\begin{array}{c}\text { Pengamat } \\
\text { 1 }\end{array}$ & $\begin{array}{c}\text { Pengamat } \\
\mathbf{2}\end{array}$ & $\begin{array}{c}\text { Rata-Rata } \\
\text { Skor }\end{array}$ & Kriteria \\
\hline I & 24 & 24 & 24 & Baik \\
\hline II & 27 & 26 & 26,5 & Baik \\
\hline III & 28 & 28 & 28 & Baik \\
\hline
\end{tabular}

Tabel 2 menunjukkan bahwa aktivitas belajar siswa terus meningkat pada tiap siklusnya dan dari siklus I sampai siklus III kriteria aktivitas belajar siswa selalu berada dalam katergori baik. Peningkatan aktivitas belajar siswa terjadi karena telah dilakukan refleksi pada tiap akhir siklus sebagai perbaikan untuk siklus berikutnya. Selain itu, peranan guru dalam membantu, membimbing, mengarahkan dan memotivasi siswa dalam belajar juga menjadi salah satu faktor terjadinya peningkatan aktivitas belajar siswa. Herlawan \& Hadija (2017) mengatakan bahwa model creative problem solving juga memberikan kesempatan kepada siswa untuk lebih aktif dalam membangun sendiri pengetahuannya dan mengembangkan pikiran dalam memahami masalah, menyelesaikan masalah, dan menjawab masalah secara sendiri, bediskusi dalam kelompok dan menyalukan pendapat secara optimal[7]. Sebagaimana dikatakan Danties dalam Mayasari, Halim, \& Suhrawandi (2013) bahwa model creative problem solving menjadikan siswa sebagai pusat pembelajaran sehingga model ini mampu membuat siswa lebih aktif dalam pembelajaran[8].

Berdasarkan uraian di atas, aktivitas belajar siswa dalam mengikuti kegiatan pembelajaran yang menerapkan model creative problem solving telah mangalami peningkatan. Sebagaimana yang dikatakan Kunandar (2010), bahwa peningkatan aktivitas siswa yaitu peningkatan jumlah siswa yang terlibat aktif belajar, meningkatnya jumlah siswa yang saling berinteraksi membahas materi 
pelajaran[10]. Sehingga dapat dikatakan bahwa penerapan model creative problem solving dalam penelitian ini telah memenuhi indikator keberhasilan, dimana model creative problem solving dapat meningkatkan aktivitas belajar siswa.

\subsection{Kemampuan Pemecahan Masalah}

Tes kemampuan pemecahan masalah siswa dilakukan dengan memberikan soal tes kemampuan pemecahan masalah bebentuk essay yang berjumlah tiga butir soal. Tiap butir soal harus diselesaikan dengan tahapan kemampuan pemecahan masalah yang terdiri dari empat tahap yaitu mengenali masalah, merencanakan strategi, menerapkan strategi, dan mengevaluasi solusi. Data hasil kemampuan pemecahan masalah siswa dari siklus I sampai siklus III dapat dilihat pada Gambar 1.

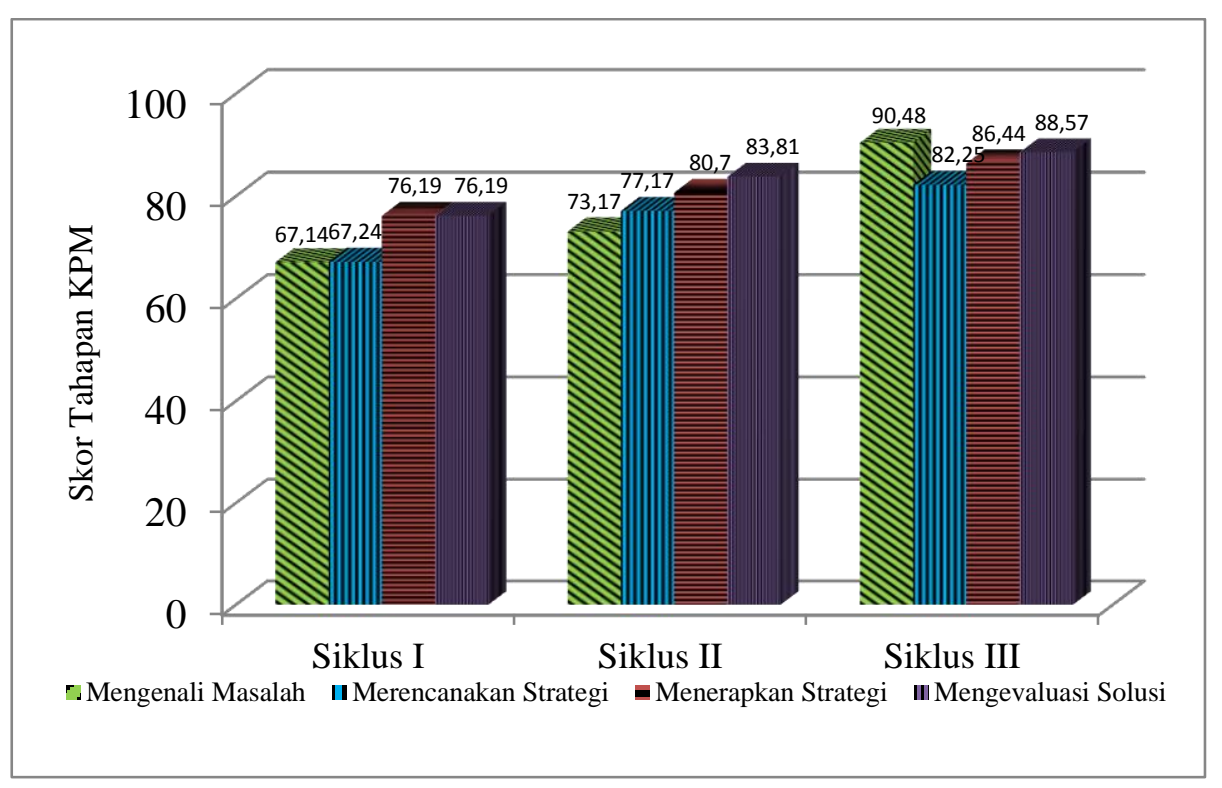

Gambar 1. Grafik skor tahapan KPM tiga siklus

Gambar 1 menunjukkan hasil peningkatan kemampuan pemecahan masalah siswa dalam tiga siklus. Melalui penerapan model creative problem solving, kemampuan pemecahan masalah siswa meningkat dari siklus I ke siklus II dan III. Tahapan kemampuan pemecahan masalah yang paling meningkat yaitu pada tahap mengenali masalah. Namun secara keseluruhan selalu terjadi peningkatan rata-rata skor kemampuan pemecahan masalah setiap siklus. Penelitian yang telah ada menyatakan bahwa salah satu kelebihan dari model creative problem solving adalah model ini tidak hanya terbatas pada tingkat pengenalan, pemahaman, dan penerapan sebuah informasi, melainkan juga melatih siswa untuk dapat menganalisis suatu masalah dan menyelesaikannya[8].

Secara keseluruhan peningkatan kemampuan pemecahan masalah pada tiap siklus disebabkan oleh beberapa faktor, diantaranya: 1) Telah dilakukan refleksi dan perbaikan pada aktivitas belajar yang menerapkan model creative problem solving tiap siklusnya; 2) siswa telah dibimbing untuk menyelesaikan soal dengan tahapan kemampuan pemecahan masalah; 3) siswa semakin lama semakin terbiasa mengikuti pembelajaran yang menerapkan model creative problem solving; 4) pengetahuan siswa terhadap konsep yang dipelajari sudah meningkat; 5) siswa sudah mampu mengidentifikasi masalah baik pada proses pembelajaran maupun pada saat menyelesaikan soal tes kemampuan pemecahan masalah, dan 6) siswa mampu mencari solusi dari suatu pemasalahan.

Skor akhir kemampuan pemecahan masalah adalah rata-rata dari keseluruhan skor siswa dalam menerapkan tahapan dan indikator kemampuan pemecahan masalah. Sehingga, dapat dilihat ketuntasan belajar siswa dalam menerapkan tahapan dan indikator kemampuan pemecahan masalah. Adapun hasil kemampuan pemecahan masalah yang diperoleh siswa dapat dilihat pada Tabel 3.

Tabel 3. Hasil Skor Tahapan KPM Siklus I, II, dan III

\begin{tabular}{ccccc}
\hline No. & $\begin{array}{c}\text { Analisis Kemampuan } \\
\text { Pemecahan Masalah }\end{array}$ & Siklus I & Siklus II & Siklus III \\
\hline 1 & Mengenali Masalah & 67,14 & 73,17 & 90,48 \\
\hline
\end{tabular}




\begin{tabular}{ccccc}
\hline No. & $\begin{array}{c}\text { Analisis Kemampuan } \\
\text { Pemecahan Masalah }\end{array}$ & Siklus I & Siklus II & Siklus III \\
\hline 2 & Merencanakan strategi & 67,24 & 77,17 & 82,25 \\
\hline 3 & Menerapkan Stategi & 76,19 & 80,70 & 86,44 \\
\hline 4 & Mengevaluasi Solusi & 76,19 & 83,81 & 88,57 \\
\hline & Rata-rata skor KPM & 71,69 & 78,71 & 86,94 \\
\hline Kategori & Sedang & Sedang & Tinggi \\
\hline Standar deviasi & 13,03 & 10,65 & 8,80 \\
\hline Ketuntasan belajar klasikal & $\begin{array}{c}60 \% \\
\text { (Tidak tuntas) }\end{array}$ & $\begin{array}{c}77,14 \% \\
\text { (Tidak tuntas) }\end{array}$ & $\begin{array}{c}88,57 \% \\
\text { (Tuntas) }\end{array}$ \\
\hline
\end{tabular}

Tabel 3 menunjukkan rata-rata skor kemampuan pemecahan masalah setiap siklus dan persentase ketuntasan belajar secara klasikal. Indikator eberhasilan tindakan pada penelitian ini, yaitu penerapan model creative problem solving dikatakan berhasil meningkatkan kemampuan pemecahan masalah siswa apabila siswa yang mendapat skor $\geq 75$ sudah mencapai $80 \%$.

Pada siklus I ini, ketuntasan belajar secara klasikal yaitu 60\%, dimana dari 35 orang siswa hanya 21 orang yang mendapatkan skor $\geq 75$ (KKM yang ditetapkan sekolah). Hasil ini menunjukkan bahwa pembelajaran pada siklus I belum tuntas secara klasikal. Berdasarkan hasil refleksi, tahapan-tahapan kemampuan pemecahan masalah siklus I berada dalam kategori sedang sehingga perlu dilakukan refleksi untuk perbaikan pada siklus berikutnya.

Pada siklus II, rata-rata skor kemampuan pemecahan masalah siswa meningkat dari siklus I yaitu 78,71, sedangkan ketuntasan belajar secara klasikal yaitu 77,14\%, dari 35 orang siswa terdapat 27 orang siswa yang mendapatkan skor $\geq 75$ (KKM yang ditetapkan sekolah). Hasil ini menunjukkan bahwa pembelajaran pada siklus II mengalami peningkatan dari siklus I, tetapi ketuntasan belajar secara klasikal masih belum tercapai. Berdasakan hasil refleksi kemampuan pemecahan masalah siklus II, hasil analisis data menunjukkan bahwa tahap mengenali masalah dan tahap merencanakan strategi masih berada pada kategori sedang, sehingga perlu dilakukan refleksi lagi terhadap hasil tes kemampuan pemecahan masalah pada siklus II agar indikator keberhasilan tindakan dapat tercapai.

Pada siklus III, rata-rata kemampuan pemecahan masalah siswa meningkat pada kategori tinggi dengan skor 86,94 dan ketuntasan belajar secara klasikal yaitu 88,57\%, dari 35 orang siswa terdapat 31 orang siswa yang mendapatkan skor $\geq 75$ (KKM yang ditetapkan sekolah). Hasil ini menunjukkan bahwa pembelajaran pada siklus III mengalami peningkatan dari siklus II, dan ketuntasan belajar secara klasikal sudah tercapai.

Dengan demikian, kemampuan pemecahan masalah siswa secara keseluruhan setelah menerapkan model creative problem solving mengalami peningkatan dari siklus I, II, dan III dan indikator keberhasilan tindakan telah tecapai pada siklus III. Seperti yang dikatakan dalam penelitian sebelumnya ${ }^{[10]}$ bahwa Creative Problem Solving dapat meningkatkan kemampuan pemecahan masalah siswa dengan menguasai empat tahap kemampuan pemecahan masalah diantaranya memahami masalah, merencanakan strategi, menjalankan rencana penyelesaian dan memeriksa hasil kembali.

\section{SIMPULAN DAN SARAN}

\subsection{Simpulan}

Berdasarkan hasil analisis data diperoleh kesimpulan, yaitu: (1) Penerapan model Creative Problem Solving dapat meningkatkan aktivitas belajar siswa pada konsep Kalor dan Perpindahan Kalor di Kelas XI MIA 4 MAN 2 Kota Bengkulu. (2) Penerapan model Creative Problem Solving dapat meningkatkan kemampuan pemecahan masalah siswa dalam belajar fisika pada konsep Kalor dan Perpindahan Kalor di Kelas XI MIA 4 MAN 2 Kota Bengkulu.

\subsection{Saran}

Berdasarkan kesimpulan di atas, dapat disarankan beberapa hal sebagai berikut: (1) Untuk meningkatkan aktivitas belajar dan kemampuan pemecahan masalah siswa salah satu model 
pembelajaran yang dapat digunakan guru adalah model Creative Problem Solving. (2) Pada proses pembelajaran fisika, guru hendaknya memberikan kesempatan lebih banyak kepada siswa untuk memecahkan persoalan berbentuk pemecahan masalah dan aplikasi materi dalam kehidupan seharihari. (3) Guru fisika yang ingin menerapkan model Creative Problem Solving dalam pembelajaran hendaknya melakukan persiapan yang lebih optimal terutama dalam pengaturan waktu, karena penerapan model Creative Problem Solving membutuhkan waktu yang lebih panjang dibandingkan dengan model pembelajaran yang lain

\section{DAFTAR PUSTAKA}

[1]Wena, M. (2012). Strategi Pembelajaran Inovatif Kontemporer Suatu Tinjauan Konseprual Operasional. Jakarta: Bumi Aksara.

[2]Supardi, K. I., \& Putri, I. R. (2010). Pengaruh Penggunaan Artikel Kimia dari Internet pada Model Pembelajaran Creative Problem Solving Terhadap Hasil Belajar Kimia Siswa SMA. Jurnal Inovasi Pendidikan Kimia, 4(1), 574-581.

[3]Suryosubroto. (2009). Proses Belajar Mengajar di Sekolah . Jakarta: RINEKA CIPTA.

[4]Hariawan, Kamaluddin, \& Wahyono, U. (2014). Pengaruh Model Pembelajaran Creative Probem Solving Terhadap Kemampuan Pemecahan Masalah Fisika pada Siswa Kelas XI SMA Negeri 4 Palu. Jurnal Pendidikan Fisika Tadulako, 1(2), 48-54.

[5]Shoimin, A. (2014). 68 Model Pembelajaran Inovetif dalam Kurikulum 2013. Yogyakarta: ARRUZZ MEDIA.

[6]Sinaga, E., Rahmad, M., \& Irianti, M. (2014). Penerapan Model Pembelajaran Problem Based Learning (PBL) Untuk Meningkatkan Kemampuan Memecahkan Masalah Fisika di Kelas XI IPA SMA N 2 Teluk Kuantan. Jurnal Pendidikan Fisika Universitas Riau, 1-15.

[7]Herlawan, \& Hadija. (2017). Peningkatan Kemampuan Pemecahan Masalah Matematis Siswa Kelas VII Melalui Penerapan Model Pembelajaran Creative Problem Solving (CPS) Berbasis Kontekstual. Jurnal Penelitian Pendidikan dan Pengajaran Matematika, 3(1), 3338.

[8]Mayasari, P., Halim, A., \& Suhrawandi, I. (2013). Model Pembelajaran Creative Problem Solving untuk Meningkatkan Pengusaan Konsep dan Keterampilan Generik Sains Siswa SMP. Jurnal Pendidikan Sains Indonesia, 57-67.

[9]Kunandar. (2010). Langkah Mudah Penelitian Tindakan Kelas Sebagai Pengembangan Profesi Guru. Jakarta: Rajawali Pers.

[10]Sari, A. D., \& Noer, S. H. (2017). Kemampuan Pemecahan Masalah Matematis dengan Model Creative Problem Solving (CPS) dalam Pembelajaran Matematika. Proseding Seminar Nasional Matematika dan Pendidikan Matematika 2017 , 245-252. 